(3) interpretation of data previously accumulated; (4) re-interpretation of data previously studied; ( $($ ) translation, bibliography, vocabulary, \&c., with annotation.

Geographical limits: the Arab countries, Israel, Afghanistan, Iran, Turkey, North Africa, the Sudan, Ethiopia, and Eritrea.

Disciplinary limits: emphasis on the social sciences, but including all telated aspects of the humanities and natural sciences.

Chronological limits: none (ancient, medieval, and modern).

All those who are currently engaged in research on the Middle East, or have completed such research since I October 1954 , are urged to submit the following information: name, address, topic of investigation, sponsoring organization (if any), date of completion ${ }_{4}$ or estimated date if still in progress, and pertinent comments on the nature of the research, sources being used, and method of approach.

Please address correspondence to:

Survey of Research, The Middle East Institute, $176 \mathrm{r}$ N. Street, N.W. Washington 6, D.C.

\title{
The Population Council, Inc., New York: Fellowship Program
}

The Population Council, Inc., of New York announces an expanded programme of fellowships for advanced training in the study of population at the pre-doctoral and post-doctoral levels. Fellowships will be available for study in universities in the United States and elsewhere. Preference will be given to qualified applicants from countries other than the United States and Europe. Fellows will normally receive support for full-time work for a period of one year. The basic stipend of $\$ 2,500$ per year may be supplemented to provide for travel expenses, maintenance of dependants, and for other exceptional expenses. Somewhat larger stipends may be granted to post-doctoral than to pre-doctoral Fellows.

Requests for further information and for application forms should be addressed to: The Population Council, Inc., 230 Park Avenue, New York 17, N.Y.

\section{Institut d'Etudes Centrafricaines (Brazzaville)}

LE Conseil Consultatif de Recherches de l'Institut d'Études Centrafricaines s'est réuni le 25 septembre 1954 à Brazzaville. M. le Professeur Trochain, le Directeur, a donné un résumé des travaux réalisés pendant l'année 1953-1954 et des programmes de recherches projetées. Dans la section Sciences Humaines, $M$. Soret avait achevé une enquête sur les besoins en main-d'œuvre dans la Vallée du Niari, et une enquête sur les caractéristiques de la maind'cuvre sans emploi à Brazzaville. En outre M. Soret s'occupait toujours de la préparation d'une carte ethnique d'A.É.F. dont la première feuille (Brazzaville) était en voie d'achèvement. La section d'Ethnologie musicale s'occupait de la préparation d'un ouvrage de synthèse 'mettant en évidence les résonances que l'on entrevoit entre ces éléments que sont la musique, le rythme, la danse, la parole ... Cet ouvrage réunira toute la documentation acquise par M. Pepper dans le Moyen-Congo et le Gabon.

\section{Linguistic Studies in Nigeria}

Dr. R. C. Apraham has been compiling a Grammar of Yoruba and an illustrated YorubaEnglish Dictionary; he spent some time in Nigeria working on these projects with the aid of grants from the Government of Nigeria, which is sponsoring publication, and from the West African Institute of Social and Economic Research. These two works will be published during the present year, concurrently with his Structure of Hausa and Hausa Extracts. On the completion of these studies he proposes to make a further stay in Nigeria with a view to preparing studies of the Ibo language. 